\title{
Koordinasi Kelembagaan dalam Penenggelaman Kapal Hasil Tindak Pidana Di Bidang Perikanan
}

\author{
Sherly Adam \\ Fakultas Hukum Universitas Pattimura, Ambon, Indonesia \\ E-mail: sherly.adam1909@gmail.com
}

\begin{abstract}
His study aims to determine to examine, analyze coordination between institutions in the framework of sinking vessels resulting from criminal acts in the field of fisheries. This research is a normative legal research (legal research). The research began with an inventory of legal regulations or laws and regulations relating to coordination between institutions in the framework of sinking vessels resulting from criminal acts in the field of fisheries. According to the Law, there are two methods of sinking ships carried out by the Government of the Republic of Indonesia, namely sinking ships through a court decision and being caught red-handed. For this reason, there is coordination between institutions in the framework of sinking fishing vessels by the Minister of Maritime Affairs and Fisheries (government) of the Republic of Indonesia, but the coordination of these institutions has not yet been implemented or carried out properly. This is due to unclear regulations regarding operational standards or guidelines for the destruction or sinking of fishing vessels which regulate the implementation, mechanism, and procedure for the destruction of ships to be used as a basis for the Ministry of Maritime Affairs and Fisheries, Prosecutors' Office and the Courts in sinking fishing vessels conducting Illegal Fishing in Indonesian waters.
\end{abstract}

Keywords: Institutional Coordination; Sinking The Skip; Marine and Fisheries Ministry.

\section{A. PENDAHULUAN}

Dibentuknya lembaga-lembaga peradilan yang khusus seperti halnya pengadilan perikanan ini, pada dasarnya dilandasi oleh spirit guna untuk penyelesaian persoalanpersoalan pada lembaga-lembaga peradilan yang ada dalam menjawab berbagai persoalan tindak pidana perikanan. Problematika yuridis yang ada dinilai jauh dari salah satu asas dalam hukum acara pidana yaitu asas sederhana, cepat dan biaya ringan. Alasan yang tak kalah penting adalah dengan semakin pesatnya kemajuan teknologi, serta semakin kompleksnya persoalan-persoalan hukum, terutama dalam bidang perikanan dibutuhkan suatu lembaga peradilan yang lebih profesional yang didukung oleh sumber daya manusia yang benar-benar menguasi persoalan-persoalan khusus terkait dengan illegal fishing tersebut. ${ }^{1}$

${ }^{1}$ Muchsin. (2006). Menyongsong Kehadiran Pengadilan Perikanan, Jakarta : Varia Peradilan Tahun 
Permasalahan yang timbul dalam penanganan kasus-kasus perikanan di tingkat kepolisian dalam hal penyidikan, kejaksaan dan pengadilan pada tahapan proses pembuktian sampai pelaksanaan eksekusi putusan pengadilan masih dirasakan ada sehingga memiliki dampak dalam penyelesaiannya. Koordinasi antara kelembagaan dari ketiga instansi tersebut seharusnya dapat berjalan dengan baik guna menghindari ego sektoral dari masing-masing lembaga tersebut.

Walaupun Undang-Undang Perikanan telah ada dan diharapkan dapat mengatasi persoalan lemahnya koordinasi tersebut tetapi masih belum maksimal mengatasi masalah tersebut. Diposisikannya Penyidik Pegawai Negeri Sipil, Tentara Nasional Indonesia Angkatan Laut (selanjutnya disebut dengan PPNS, TNI AL), Kepolisian sejajar dengan Jaksa selaku penyidik dan Penuntut Umum sebagai penyidik dalam melakukan penyidikan adanya tindak pidana perikanan, serta diberikannya kewenangan kepada Menteri untuk membentuk forum koordinasi bagi kepentingan penyidikan di tingkat daerah, belum memberikan solusi nyata bagi persoalan tersebut. Apalagi forum koordinasi tersebut notabenedibentuk pada tingkat Menteri yang kewenangan Jaksa selaku Penyidik dan Penuntut Umum dalam hal eksekusi putusan pengadilan perikanan yang berkekuatan hukum tetap yang mana amar putusan dari pengadilan perikanan ialah perampasan dan penenggelaman atau pemusnahan kapal ikan sebagai bentuk tindakan yang dilakukan oleh Kementerian Perikanan dan Kelautan Republik Indonesia. ${ }^{2}$

Penyidikan tindak pidana di bidang perikanan dapat dilakukan sendiri-sendiri atau bersama-sama oleh. PPNS Perikanan, Penyidik Perwira TNI AL, dan Penyidik Polri.Ketentuan ini dimaksudkan sebagai legitimasi bagi PPNS, Penyidik Perwira TNI AL maupun Penyidik Polri untuk melakukan penyidikan tindak pidana di bidang perikanan yang terjadi di seluruh Wilayah Pengelolaan Perikanan Republik Indonesia.Adanya tiga institusi yang melakukanpenyidikan tindak pidana di bidang perikanan berpotensi menimbulkan konflik kewenangan dalam melaksanakan tugasnya. ${ }^{3}$

Permasalahan kewenangan terkait pelaksanaan atau eksekusi putusan pengadilan perikanan terhadap tindakan penenggelaman kapal oleh Kementerian Kelautan dan Perikanan Republik Indonesia mengundang kontroversi yang cukup rumit antara Jaksa selaku Penyidik dan Penuntut Umum dengan PPNS Perikanan, karena adanya putusanputusan pengadilan terkait tidak pidana perikananlebih banyak diambil alih oleh Kementerian Perikanan dan Kelautan dalam hal ini Penyidik PPNS Perikanandan Kelautan ketimbang dilaksakan oleh Jaksa selaku Penuntut Umum yang harus mengeksekusi putusan pengadilan perikanan yakni tindakan penenggelaman kapal dalam tugas dan kewenanganyang diberikan oleh Undang-Undang Perikanan maupun UndangUndang Nomor 8 tahun 1981 tentang Kitab Undang-undang Hukum Acara Pidana (selanjutnya disingkat KUHAP).

Undang-Undang No. 45 Tahun 2009 tentang Perubahan atas Undang-Undang nomor 31 tahun 2004 tentang Perikanan, pada Pasal 69 ayat (4) menyatakan bahwa :

"Dalam melaksanakan fungsi sebagaimana dimaksud pada ayat (1) penyidik dan/atau pengawas perikanan dapat melakukan tindakan khusus berupa pembakaran dan/atau penenggelaman kapal perikanan yang berbendera asing berdasarkan bukti permulaan yang cukup".

XXI No. 247 Juni, h.4.

${ }^{2}$ Nugraha, Aditya Taufan, dan Irman.(2008), Perlindungan Hukum Zona Ekonomi Ekslusif (ZEE) Terhadap Eksistensi Indonesia Sebagai Negara Maritim.Bandung: Citra Aditya, h. 6.

${ }^{3}$ Nikijuluw, Victor P.H. (2008), Blue Water Crime: Dimensi Sosial Ekonomi Perikanan Illegal. Jakarta: Pustaka Cidesindo, h. 22. 
Pasal ini memberikan penyidik atau pengawas perikanan Indonesia memiliki hak untuk melakukan tindakan khusus seperti penenggelaman kapal asing dengan bukti permulaan yang cukup, dimana sesuai dengan penjelasan pasal ini; yang dimaksud dengan "bukti permulaan yang cukup" adalah bukti dugaan adanya tindak pidana di bidang perikanan oleh kapal perikanan berbendera asing yang menangkap atau mengangkut ikan ketika memasuki wilayah pengelolaan perikanan di Indonesia.

Tindakan penenggelaman kapal ikan sebagai bentuk penanganan terhadap kasus illegal fishing selama ini dinilai tidak berjalan secara optimal. Dapat dilihat bagaimana tarik ulur kewenangan eksekusi putusan pengadilan perikanan antara instansi Kejaksaan dengan Instansi Kementerian Kelautan dan Perikanan terkait dengan penegakan hukum atas kasus illegal fishing tidak berjalan secara sinergis, bahkan cenderung berebut kepentingannya masing-masing dengan tidak prosedural, substansial dan wewenang sebagaimana ketentuan normatif dalam Kitab Undang-undanga Hukum Acara Pidana (selanjutnya disingkat KUHAP). Undang-Undang Nomor 31 Tahun 2004 Tentang Perikanan dan Undang-Undang Nomor 4 Tahun 2016 Tentang Kejaksaan Republik Indonesia yang menempatkan kewenangan eksekusi seluruh putusan pengadilan yang berkaitan dengan tindak pidana adalah kewenangan Jaksa selaku Penyidik dan Penuntut Umum, dan kemudian Undang-Undang Nomor 31 Tahun 2004 Tentang Perikanan menempatkan Pejabat Pegawai Negeri Sipil Kelautan dan Perikanan sebagai Penyidik PPNS dan bukan sebagai eksekutor terhadap putusan pengadilan perikanan. ${ }^{4}$

Sebagai salah satu contoh kasus yang diangkat dalam penulisan ini ialah, eksekusi salah satu amar Putusan Pengadilan Perikanan Ambon Nomor : 01/Pid.Prkn/2014/PN Ambon tertanggal 18 Desember 2014 tekait dengan penenggelaman kapal ikan dipimpin dan dikomandokan langsung oleh Susi Pudjiastuti yang pada saat itu selaku Menteri Perikanan dan Kelautan Republik Indonesia kepada tim penembak TNI AL untuk menenggelamkan dua kapal asing berbendera Papua Nugini yakni KM Century 4/PNG051 dan KM Century 7/PNG-069 di perairan Teluk Ambon, pada tanggal 12 Desember 2014, setelah terbukti melakukan aktivitas pencurian ikan di perairan Arafura tanpa disertai dokumen dan izin penangkapan ikan dari pemerintah Indonesia. ${ }^{5}$

Kebijakan yang ditempuh oleh Kementrian Kelautan dan Perikanan dalam melakukan penenggelaman kapal asing yang melakukan illegal fishing di perairan Indonesia dengan tujuan memberikan efek jera kepada para pelaku illegal fishing dan demi menjaga kedaulatan Negara Kesatuan Republik Indonesia. Menurut Susi Pudjiastusi bahwa apabila kapal illegal itu dilelang dipastikan akan kembali ke pemiliknya dan digunakan untuk menangkap ikan lagi di Indonesia apalagi harga kapal yang dilelang murah sekali jauh dari harga pasar dan jelas sangat merugikan Indonesia. Kebijakan yang diambil ini telah sesuai dengan aturan dan belum akan berubah selama masih mendapat persetujuan Presiden Jokowi.

Pemberitaan tentang penenggelaman kapal akhir-akhir ini mendapat perhatian dan sorotan dari aparat penegak hukum dan masyarakat. Memang apa yang media massa beritakan mengenai tindakan pemerintah dalam hal ini Kementrian Kelautan dan Perikanan bukan merupakan suatu hal baru hanya saja pemberitaannya di media yang marak dan dianggap tidak biasanya sehingga mendapatkan atensi dari publik.

Di zaman yang modern dan maju ini dimana hubungan antar negara yang satu

\footnotetext{
4 Akhmad, Solihin. (2017), Politik Hukum Kelautan Dan Perikanan, Bandung: Nuansa Aulia, h..14. 5 http://nasional.kompas.com, Kapal.Pencuri.Ikan.Ditenggelamkan.di.Penjuru.Indonesia /
} 
dengan negara menjadi sesuatu yang penting. Tindakan tegas suatu negara kepada warga negara asing tentu saja akan mempengaruhi hubungan baik kedua negara. Jika dilihat dari kasus-kasus perikanan yang terjadi terkait dengan penenggelaman kapal asing ini maka tindakan pemerintah Indonesia yang mengebom kapal nelayan asing yang mencuri ikan dapat mempengaruhi hubungan baik kedua negara.

Mengkritisi tindakan tegas pemerintah Indonesia ini alangkah baiknya melihat permasalahan ini dari segi hukum, dimana Indonesia adalah negara hukum dan semua kegiatan yang dilakukan di Indonesia haruslah dilindungi dan sesuai dengan hukum yang berlaku.

Berdasarkan uraian latar belakang diatas, maka permasalahan dalam penulisan ini adalah "Apakah terdapat koordinasi antara Kementrian Kelautan dan Perikanan, Kejaksaan dan Pengadilan dalam rangka penenggelaman kapal hasil tindak pidana di bidang perikanan".

\section{B. METODE PENELITIAN}

Metode penelitian yang digunakan adalah penelitian yuridis Nnormatif. Tipe penelitian bersifat deskriptif analitis. Sumber bahan hukum yang digunakan bahan hukum primer dan bahan hukum sekunder. Teknik pengumpulan melalui studi kepustakaan dan selanjutnya dianalisis melalui cara deskripsi dengan menggunakan metode kualitatif.

\section{PEMBAHASAN}

\section{Kelembagaan Yang Terkait Dalam Proses Eksekusi Perkara}

KUHAP mengatur fungsi dan kewenangan Jaksa sebagai Penuntut Umum dan melaksanakan putusan Pengadilan yang telah memperoleh kekuatan hukum tetap (Pasal 1 angka 6 huruf a KUHAP). KUHAP merumuskan demikian, karena perumusan tersebut berkaitan dengan rangkaian ketentuan lainnya dalam KUHAP. Adanya ketentuan pasal 284 ayat 2 KUHAP maka Jaksa berwenang untuk melakukan penyidikan setiap tindakan pidana yang memiliki ketentuan khusus acara pidana, terlepas dari apakah wewenang untuk melakukan penyidikan atas tindak pidana tersebut atau tidak ${ }^{6} .{ }^{39}$ Jadi kriteria kewenangan penyidikan bagi Jaksa tersebut berdasarkan pada apakah dalam undangundang tertentu untuk terdapat ketentuan khusus acara pidana.

Pasal 14 huruf j KUHAP juga menyatakan bahwa Jaksa berwenang melaksanakan penetapan Hakim. Sejalan dengan untuk sesuai dengan ketentuan Pasal 279, Jaksa melaksanakan putusan Pengadilan yang telah memperoleh kekuatan hukum tetapi dan untuk melaksanakan putusan tersebut panitera mengirimkan surat putusan yang dilaksanakan dengan segera (Pasal 197 ayat 3).

Undang-Undang No. 16 Tahun 2004 tentang Kejaksaan Republik Indonesia Bab II mengenai susunan Kejaksaan bagian kedua, dalam Pasal 8 menyebutkan:

1) Jaksa diangkat dan diberhentikan oleh Jaksa Agung.

2) Dalam melaksanakan tugas dan wewenangnya, Jaksa bertindak untuk dan atas nama negara serta bertanggung jawab menurut saluran hierarki.

6 Husein, Harun M. (1991), Penyidikan Penuntutan dalam Proses Pidana, Cetakan Pertama, Jakarta: Rineka Cipta, h. 228

131 |S A S I Vo1.26 No.1, Januari- Maret 2020 
3) Demi keadaan dan kebenaran berdasarkan Ketuhanan Yang Maha Esa, Jaksa melakukan penuntutan dengan keyakinan berdasarkan alat bukti yang sah.

4) Dalam melaksanakan tugas dan wewenangnya, Jaksa senantiasa bertindak berdasarkan hukum dan mengindahkan norma-norma keagamaan, kesopanan, kesusilaan, serta wajib menggali dan menjunjung tinggi nilai-nilai kemanusiaan yang hidup dalam masyarakat, serta senantiasa menjaga kehormatan dan martabat profesinya.

5) Dalam hal melaksanakan tugas sebagaimana dimaksud pada ayat (4), Jaksa diduga melakukan tindak pidana maka pemanggilan, pemeriksaan, penggeledahan, penangkapan dan penahanan terhadap Jaksa yang bersangkutan hanya dapat dilakukan atas ijin Jaksa Agung.

Tugas dan Wewenang Kejaksaan dapat diketahui dalam Bab III Bagian 1 Undangundang No. 16 Tahun 2004 tentang Kejaksaan Republik Indonesia disebut dalam beberapa pasal antara lain :

Pasal 30 menyebutkan bahwa :

1) Di bidang pidana, Kejaksaan mempunyai tugas dan wewenang:

a) Melakukan penuntutan

b) Melaksanakan penetapan Hakim dan putusan Pengadilan yang telah

c) Memperoleh kekuatan hukum tetap;

d) Melakukan pengawasan terhadap pelaksanaan putusan pidana bersyarat, putusan pidana pengawasan dan keputusan lepas bersyarat;

e) Melakukan penyelidikan terhadap tindak pidana tertentu berdasarkan undang-undang;

f) Melengkapi berkas perkara tertentu dan untuk itu dapat melakukan pemeriksaan tambahan sebelum dilimpahkan ke Pengadilan yang dalam pelaksanaannya dikoordinasikan dengan penyidikan.

2) Di bidang perdata dan tata usaha negara, Kejaksaan dengan kuasa khusus dapat bertindak baik di dalam maupun di luar Pengadilan untuk dan atas nama negara atau pemerintah.

3) Dalam bidang ketertiban dan ketenteraman umum, Kejaksaan turut menyelenggarakan kegiatan:

a) Peningkatan kesadaran hukum masyarakat;

b) Pengamanan kebijakan penegakan hukum;

c) Pengawasan aliran kepercayaan yang dapat membahayakan masyarakat dan negara;

d) Pencegahan penyalahgunaan dan/atau penodaan agama;

e) Penelitian dan pengembangan hukum serta statistik kriminal;

Pasal 31 menyatakan bahwa :

Kejaksaan dapat meminta kepada Hakim untuk menempatkan seorang terdakwa di rumah sakit, tempat perawatan jiwa, atau tempat lain yang layak karena yang bersangkutan tidak mampu berdiri sendiri atau disebabkan oleh hal-hal yang dapat membahayakan orang lain, lingkungan atau dirinya sendiri.

Pasal 32 menyatakan bahwa :

Di samping tugas dan wewenang tersebut dalam undang-undang ini, Kejaksaan dapat diserahi tugas dan wewenang lain berdasarkan undang-undang.

Pasal 33 menyatakan bahwa : 
Dalam melaksanakan tugas dan wewenangnya, Kejaksaan membina hubungan kerja sama dengan badan penegak hukum dan keadilan serta badan negara atau instansi lainnya.

Pasal 34 menyatakan, yaitu :

Kejaksaan dapat memberikan pertimbangan dalam bidang hukum kepada instansi pemerintah lainnya.

Dalam rangka supremasi hukum, fungsi Kejaksaan sangat penting dalam mewujudkan hukum in concreto. Mewujudkan hukum in concreto bukan hanya fenomena Pengadilan atau Hakim, tetapi termasuk dalam pengertian tersebut adalah pejabat administrasi pemberi pelayanan hukum, dan penegak hukum. Kejaksaan dan kepolisian merupakan pranata publik penegak hukum, yang dalam sistem peradilan pidana justru merupakan sumber awal dari suatu proses peradilan. Sebagaimana badan negara yang menjalankan fungsi penegakan hukum, Kejaksaan dalam melaksanakan fungsinya tersebut membutuhkan, kemandirian dan independensi bersifat tidak memihak, tanpa membeda-bedakan asal usul, kewarganegaraan, agama atau etnik, dan mempunyai posisi sentral dalam penegakan hukum, karena pertama sebagai penyandang azas dominus litis institusi yang dapat menyatakan seseorang menjadi terdakwa, kedua sebagai executive abmtenaar pelaksana keputusan Pengadilan yang telah mempunyai kekuatan hukum tetap, ketiga hanya Jaksa Agung yang dapat mengesampingkan perkara demi kepentingan umum berdasarkan azas oportunitis dan keempat sebagai pengacara negara kesemuanya itu sulit terwujud jika secara struktural Kejaksaan Republik Indonesia masih berada di bawah presiden masuk lingkup eksekutif.

Kejaksaan sebagai salah satu aparatur Penegak Hukum yang melaksanakan tugas terutama di bidang penuntutan serta turut menyelenggarakan sebagian tugas umum pemerintah dan pembangunan di bidang hukum. Menurut undang-undang, tugas badan Penuntut Umum itu adalah mempertahankan undang-undang, melakukan penyelidikan dan penyidikan lanjutan, menuntut kejahatan dan pelanggaran, dan melaksanakan putusan Pengadilan pidana ${ }^{7}$.

Dalam pelaksanaan tugas tersebut, Kejaksaan sebagai bagian dari aparatur pemerintahan perlu secara terus menerus dan berkesinambungan mengaktualisasikan diri pada perkembangan masyarakat dan tantangan yang dihadapinya. Sehingga secara strategis peranan Kejaksaan mampu mewarnai dan membentuk wajah penegak hukum Indonesia, yaitu terwujudnya kebenaran dan keadilan yang aspiratif dengan masyarakat. Oleh karena itu Kejaksaan sebagai aparat penegak hukum harus responsif terhadap tuntutan aktual yang berkembang saat ini dan dapat memainkan perannya secara optimal.

Peran penegak hukum dalam hal ini Kejaksaan sebagai aparat berkaitan dengan Jaksa sebagai executeur atau penangung jawab pelaksanaan putusan Hakim yang harus segera atau selekas mungkin melaksanakan putusan Hakim, baik yang menyangkut orang maupun yang menyangkut barang bukti, putusan Hakim baru dapat dilaksanakan apabila putusan itu telah mempunyai kekuatan hukum tetap (in kracth van gewijsde $)^{8}$. Adapun tugas pelaksanaan keputusan Hakim yang telah mempunyai kekuatan hukum tetap dibebankan kepada Penuntut Umum (Jaksa) sebagaimana diatur dalam Pasal 35 ayat (1) UU No. 48 Tahun 2009 tentang Kekuasaan Kehakiman

7 Surachman, R.M. Hamzah, Andi. (1996), Jaksa di Berbagai Negara, Peranan dan Kedudukannya, Cetakan Pertama, Jakarta: Sinar Grafika, h. 31.

${ }^{8}$ Prakoso, Djoko. (1985), Eksistensi Jaksa di Tengah-Tengah Masyarakat, Cetakan Pertama, Jakarta: Ghalia.

133 |S A S I Vo1. 26 No.1, Januari- Maret 2020 
Putusan hakim atau putusan pengadilan adalah suatu pernyataan yang oleh hakim, sebagai Pejabat Negara yang diberi wewenang untuk itu, diucapkan di persidangan dan bertujuan untuk mengakhiri atau menyelesaikan suatu perkara atau sengketa antara para pihak.

Pasal 10 KUHP dikenal ada dua jenis hukuman pidana, yaitu pidana pokok dan pidana tambahan. Pidana pokok merupakan hukuman yang wajib di jatuhkan hakim yang terdiri atas pidana mati, pidana penjara, pidana kurungan, dan pidana denda. Sedangkan pidana tambahan sifatnya tidak wajib dijatuhkan hakim, yaitu berupa pencabutan hak-hak tertentu, perampasan barang tertentu, dan pengumuman putusan hakim.

\section{Kewenangan Penenggelaman Kapal Dalam Undang-Undang Perikanan}

Kewenangan pada hakikatnya tidak dapat dilepaskan dari pembahasan tentang kekuasaan, kewenangan, dan wewenang. Oleh karena itu agar dapat lebih memahami pengertian yang terkandung dalam istilah kewenangan, dibahas pula pengertian kekuasaan dan pengertian wewenang. Menurut Miriam Budiarjo,kekuasaan biasanya berbentuk hubungan dalam arti bahwa "ada satu pihak yang memerintah dan pihak lain yang diperintah" (the rule and theruled). ${ }^{9}$

Kewenangan merupakan bagian dari kekuasaan, karena pada hakikatnya kewenangan adalah kekuasaan yang dilembagakan (institutionalized power) atau kekuasaan yang diabsahkan atau kekuasaan formal (formal power). Kewenangan merupakan kekuasaan yang diperoleh secara konstitusional, karena kekuasaan juga bisa diperoleh secara inkonstitusional. Pengertian Konstitusi dalam hal ini bisa diartikan secara luas dan dapat pula diartikan secara sempit. Konstitusi dalam arti luas adalah hukum tata negara, sedangkan dalam arti sempit adalah Undang-Undang Dasar.

Istilah kewenangan sering disejajarkan dengan istilah wewenang dan secara konseptual seringkali disejajarkan dengan istilah "bevoegheid" dalam hukum Belanda,walaupun sebenarnya ada sedikit perbedaan antara istilah "kewenangan" dengan istilah "bovoegheid". Perbedaan tersebut terletak pada karakter hukumnya, dimana istilah "bevoegheid" di Belanda digunakan dalam konsep hukum publik dan dalam hukum privat. Sementara istilah kewenangan atau wewenang biasanya digunakan dalam konsep hukum publik.

Walaupun ada yang membedakan pengertian kewenangan dan pengertian wewenang, namun pada umumnya kewenangan diartikan sama dengan wewenang. Hal ini juga sejalan dengan pengertian kewenangan menurut Kamus Besar Bahasa Indonesia yang diartikan sama dengan wewenang, yaitu hak dan kekuasaan untuk melakukan sesuatu. ${ }^{10}$

Upaya penanggulangan illegal fishing telah dilakukan dengan melahirkan UndangUndang Nomor 31 Tahun 2004 Tentang Perikanan (UU Perikanan) pada tanggal 6 Oktober 2004 yang pokoknya mengatur tentang pengelolaan perikanan untuk meningkatkan kemakmuran dan keadilan guna pemanfaatan yang sebesar-besarnya bagi kepentingan bangsa dan negara dengan tetap memperhatikan prinsip kelestarian sumber daya ikan dan lingkungannya serta kesinambungan pembangunan perikanan nasional. ${ }^{11}$

Kewenangan Menteri Kelautan dan Perikanan yang dalam hal ini Penyidik Pegawai Negeri Sipil (PPNS) Perikanan dan Kelautan, Kepolisian, dan TNI Angkatan Laut dapat

9 Budiarjo, Miriam. (1998). Dasar-Dasar Ilmu Politik, Jakarta: Gramedia Pustaka Utama, h. 36

10 Tim Penyusun, (1989), Kamus Besar Bahasa Indonesia, Jakarta: Balai Pustaka, h. 1170.

11 Kementerian Kelautan dan Perikanan. (2015). Laporan Kinerja Satu Tahun Kementerian Kelautan Dan Perikanan Tahun 2015. Jakarta. h. 71. 
bertindak sesuai ketentuan pasal 1 Butir (2) KUHAP sebagai lex generalis, bahwa tindakan penyidikan tiada lain daripada "rangkaian" tindakan mencari dan mengumpulkan bukti, agar peristiwa tindak pidananya terang serta tersangkanya dan berkas pekara tindak pidananya dapat diajukan kepada penuntut umum. ${ }^{12}$

Dalam artian bahwa Kementerian Kelautan dan Perikanan melalui Penyidik Pegawai Negeri Sipil diberi kewenangan yang terbatas dalam melakukan penyidikan tindak pidana di bidang perikanan, yakni tidak diberi kewenangan untuk penangkapan dan/atau penahanan, kewenangan hanya sebatas pada:

1) Menerima laporan ataupengaduan dari seseorang tentang adanya pelanggaran;

2) Melakukan pemanggilan danpemeriksaan terhadap tersangka dan pelaku pelanggaran;

3) Mengeledah kapal perikanan, saranaangkutan dan tempat menyimpan, mendinginkan dan mengawetkan ikan yang diduga dipergunakan dalam atau menjadi tempat melakukan pelanggaran; dan

4) Melakukan penyitaanikan yang dihasilkan, alat-alat dan surat yang digunakan dalam melakukan perbuatan pelanggaran.

Aplikasi peran jaksa dalam penegakan hukum pidana untuk tindak pidana perikanan dilaksanakan melalui kegiatan penuntutan dan eksekusi ;

a) Penuntutan: Menerima pemberitahuan dimulainya penyidikan; Menerima penyerahan tahap (berkas pemeriksaan); Mengembalikan berkas yang belum lengkap; Melengkapi berkas yangbelum lengkap; Pemberitahuan kepada penyidik tentang penunjukkan penuntut umum; Menerima penyerahan tahap II (berkas pemeriksaan, tersangka dan barang bukti); Perpanjangan penahanan; Mengisi riwayat perkara; Membuat surat dakwaan; Pelimpahan perkara ke Pengadilan Perikanan; Pemanggilan tersangka dan saksi; Pembacaan surat dakwaan; Membuat tangkisan dan perlawanan; Mengadakan pembuktian; Membuat laporan hasil sidang; Membuat tuntutan pidana; Membuat replik; Menerima atau menolak putusan pengadilan; Melaksanakan penetapan hakim; Melakukan upaya hukum.

b) Eksekusi: Melaksanakan putusan pengadilan yang telah mempunyai kekuatan hukum tetap berupa: Hukuman pokok (pidana badan, hukuman sementara, hukuman seumur hidup, hukuman bersyarat, pidana denda). Hukuman tambahan: Perampasan barang untuk negara, pengembalian barang. Putusan pengadilan atas perkara tindak pidana perikanan dapat diterima atau ditolak baik oleh Penuntut Umum maupun terdakwa/penasehat hukum terdakwa. Putusan pengadilan yang diterima oleh kedua belah pihak pelaksanaan eksekusinya dilakukan oleh Penuntut Umum, sedangkan putusan pengadilan yang ditolak baik oleh Penuntut Umum maupun terdakwa/penasehat hukum terdakwa atau oleh salah satu pihak saja dapat dilakukan upaya hukum sesuai dengan jenis putusan pengadilan. Putusan pengadilan yang membebaskan terdakwa atau menyatakan terdakwa tidak bersalah dapat diajukan kasasi ke Mahkamah Agung, sedangkan putusan pengadilan yang memidana terdakwa tetapi dirasakan kurang adil dapat diajukan banding ke Pengadilan Tinggi. ${ }^{13}$

Dalam UU Perikanan tidak ada sesuatu hal baru yang diharapkan dapat mengatasi

${ }^{12}$ Dahuri, Rohmin. (2012), Petunjuk Teknis Penyelesaian Perkara Tindak Pidana Perikanan, Jakarta: Pusdiklat Kejagung RI, h. 7.

${ }^{13}$ Marlina dan Faisal. (2013), Aspek Hukum Peran Masyarakat Dalam Mencagah Tindak Pidana Perikanan. Jakarta: Sofmedia, h.. 32. 
persoalan lemahnya koordinasi tersebut. Diposisikannya PPNS, TNI AL, Kepolisian sejajar dengan Jaksa selaku penyidik dan Penuntut Umum sebagai penyidik dalam melakukan penyidikan adanya tindak pidana perikanan, serta diberikannya kewenangan kepada Menteri untuk membentuk forum koordinasi bagi kepentingan penyidikan di tingkat daerah, belum memberikan solusi nyata bagi persoalan tersebut. Apalagi forum koordinasi tersebut notabene dibentuk pada tingkat Menteri yang menyabutasi kewenangan Jaksa selaku Penuntut Umum dalam hal eksekusi Putusan Pengadilan Perikanan yang berkekuatan hukum tetap. ${ }^{14}$

Permasalahan kewenangan terkait pelaksanaan atau eksekusi putusan pengadilan perikanan mengundang kontroversi yang cukup rumit antara Jaksa selaku Penuntut Umum dengan Menteri Kelautan dan Perikanan Susi Pudjiastuti, karena adanya putusan-putusan pengadilan terkait perkara tidak pidana perikanan lebih banyak diambil alih oleh Susi Pudjiastuti selaku Menteri Kelautan dan Perikanan ketimbang dilaksakan oleh Jaksa selaku Penuntut Umum yang harus mengeksekusi Putusan Pengadilan Perikanan sesuai tugas dan kewenanganyang diberikan oleh Undang-Undang Perikanan, Undang-Undang Kejaksaan, KUHAP maupun Undang-Undang Kekuasaan Kehakiman.

Penanganan illegal fishing selama ini dinilai tidak berjalan secara optimal. Hal tersebut terlihat dari tarik ulur kewenangan eksekusi putusan pengadilan perikanan antara instansi Kejaksaan dengan Instansi Kementerian Kelautan dan Perikanan yang terkait dalam kaitan dengan penegakan hukum di bidang illegal fishing tidak berjalan secara sinergis, bahkan cenderung berebut dan bersaing sesuai dengan kepentingannya masingmasing untuk mencapai popularitas.

\section{Koordinasi Kelembagaan}

Pengawas Perikanan Kementerian Kelautan dan Perikanan (KKP) sebagai salah satu ujung tombak dalam melaksanakan program KKP dituntut untuk lebih profesional dan mampu bersinergi dengan aparat penegak hukum lainnya. Terkait hal itu, KKP akan terus berupaya untuk meningkatkan sinergitas dan kapasitas pengawas perikanan, terutamadalam melakukan pencegahan dan pemberantasan Illegal, Unreported, and Unregulated (IUU) Fishingdi Wilayah Perairan Indonesia.

Pengawas Perikanan dalam pelaksanaan tugasnya harus bekerja secara profesional dengan merujuk pada tiga pilar utama, yaitu tepat waktu dalam memberikan pelayanan publik, tepat sasaran dalam penanganan kasus pelanggaran, dan berintegritas dengan memiliki kehormatan (dignity) karena moral dan rasa tanggung jawabnya pada negara dan bangsa. Pengawas perikanan juga harus mampu bersinergi/bekerja sama dalam teamwork dengan aparat penegakkan hukum lainnya, maupun antar Pengawas Perikanan di seluruh Indonesia, dengan membangun net-working sesama Pengawas Perikanan untuk bertukar informasi, dan berkoordinasi dalam pelaksanaan tugas di lapangan.

Koordinasi dengan aparat penegak hukum lain seperti TNI AL, Polri dan, juga menjadi hal yang sangat penting untuk mewujudkan sinergitas dalam pelaksanaan pengawasan. Sinergitas dengan TNI AL dilakukan terutama dalam gelar operasi/patroli bersama dan bertukar informasi dalam penyidikan tindak pidana perikanan. Sedangkan sinergitas dengan Polri dilakukan dalam pelimpahan penyidikan kapal perikanan yang ditangkap di perairan Zona Ekonomi Ekskluisif Indonesia, serta percepatan proses pemberkasan perkara dengan Kejaksaan. Tak hanya itu, aparat Pengawas Perikanan juga

\footnotetext{
${ }^{14}$ Nugraha, Aditya Taufan, dan Irman. (2008), Perlindungan Hukum Zona Ekonomi Ekslusif (ZEE) Terhadap Eksistensi Indonesia Sebagai Negara Maritim. Bandung: Citra Aditya, h. 6.
} 
harus mampu mendorong dan meningkatkan partisipasi masyarakat untuk membantu pengawasan di lapangan melalui pembinaan Kelompok Masyarakat Pengawas (Pokmaswas) bersama Kementrian Kelautan dan Perikanan Provinsi/ Kabupaten/Kota.

Pelaksanaan tugas Pengawas Perikanan diatur melalui Peraturan Menteri Kelautan dan Perikanan (PERMEN-KP) Nomor 17/PERMEN-KP/2014 tentang Pelaksanaan Tugas Pengawas Perikanan, yang merupakan peraturan pelaksanaan dari Undang-Undang Nomor 45 Tahun 2009 tentang Perubahan Atas Undang-Undang Nomor 31 Tahun 2004 tentang Perikanan. Dalam Peraturan menteri Kelautan dan Perikanan yang diundangkan oleh Kementerian Hukum dan HAM pada tanggal 24 April 2014, memiliki ruang lingkup pengaturan yang meliputi Pengawas Perikanan, tata cara pelaksanaan tugas, tindak lanjut hasil pengawasan, pelaporan, dan pembinaan Pengawas Perikanan. Peraturan Menteri ini menjadi payung hukum bagi Pengawas Perikanan dalam pelaksanaan tugas di lapangan, sehingga tidak ada lagi keragu-raguan dalam bertindak.

Sebagaimana diatur dalam Permen tersebut, pelaksanaan tugas Pengawas Perikanan dilaksanakan Wilayah Pengelolaan Perikanan Republik Indonesia (WPPRI), kapal perikanan, pelabuhan perikanan dan/atau pelabuhan lain-nya yang ditunjuk. Selain itu juga mencakup pelabuhan tangkapan, sentra kegiatan perikanan, area pembenihan ikan, area pembudidayaan ikan, Unit Pengolahan Ikan (UPI), dan/atau kawasan konservasi perairan. Apabila dalam pelaksanaan pengawasan perikanan ditemukan atau patut diduga adanya tindak pidana perikanan dan adanya bukti permulaan yang cukup, Pengawas Perikanan wajib menindaklanjuti dengan menyerahkan kepada penyidik di bidang perikanan untuk diproses lebih lanjut.

Kesepakatan yang dibentuk sebagai hasil keputusan bersama antara Departemen Kelautan dan Perikanan Republik Indonesia dengan Kepolisian Negara Republik Indonesia No: 10/KB/Dep.KP/2003 atau No. Pol: B/4042/VIII/2003 tentang Penegakan Hukum di Bidang Kelautan dan Perikanan didasari bahwa Departemen Kelautan dan Perikanan merupakan pihak yang bertanggung jawab dalam pengelolaan kegiatan perikanan tangkap, perikanan budi daya, pengawasan sumber daya kelautan dan perikanan, peningkatan kapasitas kelembagaan dan pemasaran, pemberdayaan pesisir dan pulau-pulau kecil serta riset kelautan dan perikanan. Sementara itu, pihak kepolisian merupakan pihak yang bertanggung jawab dalam memelihara keamanan dan ketertiban masyarakat, menegakkan hukum dan memberikan perlindungan, pengayoman, dan pelayanan kepada masyarakat serta melindungi kepentingan nasional. Salah satu tujuan kesepakatan sebagaimana dituangkan dalam Pasal 1 adalah meningkatkan koordinasi dan kerjasama dalam rangka pelaksanaan penegakan hukum terhadap tindak pidana yang terkait dengan bidang kelautan dan perikanan di wilayah perairan Indonesia.

Beberapa kesepakatan yang dapat diambil, antara lain adalah dalam rangka mendorong dan mengembangkan sistem pengamanan di lingkungan KKP maka kepolisian menyiapkan tenaga pelatih profesional untuk melakukan pembinaan dan pelatihan satuan pengamanan yang dimiliki oleh jajaran KKP. Oleh karena itu, kesepakatan bersama tersebut dapat menjadi landasan hukum yang jelas bagi kewenangan PPNS Perikanan, khususnya yang terdapat dalam jajaran KKP. Untuk mewujudkan penegakan hukum di bidang perikanan yang lebih baik dan berdaya guna, Menteri mengeluarkan Peraturan Per. 13/Men/2005 tentang forum Koordinasi Penanganan Tindak Pidana di Bidang Perikanan yang merupakan peraturan pelaksanaan Pasal 73 ayat (3) UU Nomor 31 Tahun 2004 juncto UU 45 Tahun 2009 tentang Perikanan. Dalam Pasal 1 PermenKP ini, diatur khusus mengenai kedudukan tugas dan fungsi lembaga forum koordinasi. 
Permasalahan kewenangan terkait pelaksanaan atau eksekusi putusan pengadilan perikanan juga mengundang kontroversi yang cukup rumit antara Jaksa selaku Penuntut Umum dengan Mantan Menteri Kelautan dan Perikanan Susi Pudjiastuti, karena adanya putusan-putusan pengadilan terkait perkara tidak pidana perikanan lebih banyak diambil alih oleh Susi Pudjiastuti yang pada saat itu selaku Menteri Kelautan dan Perikanan ketimbang dilaksakan oleh Jaksa selaku Penuntut Umum yang harus mengeksekusi Putusan Pengadilan Perikanan sesuai tugas dan kewenanganyang diberikan oleh UndangUndang Perikanan, Undang-Undang Kejaksaan, KUHAP maupun Undang-Undang Kekuasaan Kehakiman.

Penanganan illegal fishing selama ini dinilai tidak berjalan secara optimal. Hal tersebut terlihat dari tarik ulur kewenangan eksekusi putusan pengadilan perikanan antara instansi Kejaksaan dengan Instansi Kementerian Kelautan dan Perikanan yang terkait dalam kaitan dengan penegakan hukum di bidang illegal fishing tidak berjalan secara sinergis, bahkan cenderung berebut dan bersaing sesuai dengan kepentingannya masingmasing untuk mencapai popularitas.

Ketentuan normatif Pasal 270 KUHAP yang menentukan bahwa kewenangan eksekusi dilakukan oleh Jaksa, setelah panitera mengirimkan salinan surat putusan kepadanya. Akan tetapi dalam pelaksanaannya, eksekusi putusan pengadilan perikanan yang telah berkekuatan hukum tetap dilaksanakan oleh Susi Pudjiastuti selaku Menteri Kelautan dan Perikanan.

Penegasan kewenangan Jaksa selaku Penuntut Umum terlihat pada Surat Edaran Jaksa Agung Muda Tindak Pidana Umum B-128/E/3/1995 Tentang Tugas dan Tanggung jawab Jaksa Selaku Eksekutor Putusan Pengadilan ialah "KUHAP telah menetapkan kewenangan bahwa Jaksa adalah Eksekutor terhadap Putusan Pengadilan yang telah memperoleh kekuatan hukum tetap dan untuk itu Panitera mengirimkan salinan Surat Putusan kepadanya (pasal 270 jo pasal 1 butir 6a KUHAP). Terhadap itulah Eksekusi putusan Pengadilan yang telah memperoleh kekuatan hukum tetap sepenuhnya merupakan tugas dan kewenangan Jaksa selaku Penuntut Umum. ${ }^{15}$

Kewenangan Jaksa Penuntut Umum dalam hal pelaksanaan eksekusi terhadap seluruh putusan pengadilan yang berkaitan dengan tindak pidana dipertegas lagi dengan diundangkannya Undang-Undang Nomor 16 Tahun 2004 Tentang Kejaksaan Republik yang dalam pasal 1 ayat (1) mengatakan bahwa;

"Jaksa adalah pejabat fungsional yang diberi wewenang oleh undang-undanguntuk bertindak sebagai penuntut umum dan pelaksana putusan pengadilan yangtelah memperoleh kekuatan hukum tetap serta wewenang lain berdasarkanundangundang".

Lanjutan rumusan normatif pada pasal 1 ayat (2) UU Kejaksaan mengatakan bahwa;

"Penuntut Umum adalah Jaksa yang diberi wewenang oleh Undang-Undangini untuk melakukan penuntutan dan melaksanakan penetapan hakim".

Secara kelembagaan, pengkhususan pengaturan hukum tentang tugas dan wewenang kejaksaan diatur dalam pasal 30 ayat (1) poin b dan poin c UU Kejaksaan yakni :

a) Di bidang pidana, kejaksaan mempunyai tugas dan wewenang :

15 Gatot: Supramono (2014), Hukum Acara Pidana \& Hukum Pidana Di Bidang Perikanan. Jakarta: Rineka Cipta, h. 39.

138 | S A S I Vol. 26 No.1, Januari- Maret 2020 
b) melaksanakan penetapan hakim dan putusan pengadilan yang telahmemperoleh kekuatan hukum tetap;

c) melakukan pengawasan terhadap pelaksanaan putusan pidana bersyarat,putusan pidana pengawasan, dan keputusan lepas bersyarat".

Penegasan khusus dalam lingkup peradilan Indonesia terlihat dalam Pasal 54 ayat (1) Undang-Undang Kekuasaan Kehakima yang menyatakan bahwa :

"Pelaksanaan Putusan Pengadilan dalam perkara pidana dilaksanakan oleh Jaksa."

Terhadap rumusan normatif itulah dalam praktek peradilan, khususnya penyelenggaraan eksekusi Putusan Pengadilan Perikanan yang telah berkekuatan hukum tetap, Menteri Kelautan dan Perikanan tidak memiliki kewenangan yang diberikan oleh Negara melalui ketentuan peraturan perundang-undangan secara hirarkhis, kecuali dalam hal pengawasan dan diundang untuk menyaksikan eksekusi salah satu amar putusan pengadilan perikanan yakni penenggelaman kapal ikan yang dirampas untuk dimusnahkan atau benar-benar telah selesai dieksekusi.

Dalam artian bahwa secara substansial, procedural dan wewenang telah menempatkan kelembagaan Kementerian Kelautan dan Perikanan (PPNS) sebagai penyidik yang tidak seharusnya melaksanakan eksekusi putusan pengadilan perikanan yang telah memperoleh kekuatan hukum tetap, dan menempatkan Jaksa yang dalam hal ini selaku Penuntut Umum dengan kewenangan melaksanakan Amar Putusan Pengadilan Perikanan yang telah memperoleh kekuatan hukum tetap (purna adjudikasi).

Hal ini sesuai dengan Pasal 270 KUHAP yang berbunyi "Pelaksanaan putusan pengadilan yang telah memperoleh kekuatan hukum tetap dilakukan oleh jaksa, yang untuk itu panitera mengirimkan salinan surat putusan kepadanya". Pasal 1 angka 6 huruf b jo Pasal 13 KUHAP dinyatakan bahwa Penuntut Umum adalah jaksa yang diberi wewenang oleh undang-undang ini untuk melakukan penuntutan dan melaksanakan penetapan hakim. Akan tetapi pelaksanaan peneggelaman kapal perikanan dilakukan Susi Pudjistuti selaku Menteri Kelautan dan Perikanan yang secara substansial, prosedural dan wewenang telah melanggar ketentuan normatif sebagai perbuatan melanggar hukum penguasa dengan mengambil alih kewenangan Jaksa selaku Penuntut Umum untuk memimpin dan mengomandokan eksekusi Putusan Pengadilan Perikanan yang telah berkekuatan hukum tetap.

Selama ini lingkup tugas dan tanggung jawab PPNS Perikanan dalam sistem penegakan hukum di Indonesia menyisakan banyak permasalahan, tidak saja terkait adanya tiga institusi yang diberi kewenangan untuk melakukan penyidikan atas suatu tindak pidana perikanan, tetapi juga masih terdapatnya tumpang tindih kewenangan penyidikan antara beberapa institusi. Akibatnya, antar institusi penyidik muncul kesan kurang terjalin koordinasi dan sinergitas yang dapat berdampak pada berkurangnya kredibilitas institusi penegak hukum dimata masyarakat. Hanya karena muncul sikap ego sektoral di antara masing-masing intitusi penegak hukum, rasa keadilan masyarakat yang seharusnya dijunjung tinggi harus dikorbankan. Hal ini yang menjadi masalah klasik pada proses penegakan hukum di bidang perikanan karena adanya tiga penyidik yang berwenang

Polemik seputar persoalan penenggelaman kapal pencuri ikan apakah sebaiknya diteruskan atau dihentikan seharusnya tidak perlu terjadi bila koordinasi antar kementerian dapat benar-benar diperkuat, hal itu dapat menimbulkan kegaduhan serta dapat dinilai sebagai bentuk kelemahan koordinasi antar kementerian dalam pelaksanaan penegakan hukum di Indonesia. Untuk penegakan hukum sepanjang sudah sesuai dengan 
ketentuan perundang-undangan harus tetap dilaksanakan sebagai bentuk penindakan untuk menjaga kedaulatan laut Nusantara. ${ }^{16}$.

Menurut Undang-Undang, ada dua cara penenggelaman kapal yang dilakukan oleh Pemerintah Republik Indonesia yaitu penenggelaman kapal melalui putusan pengadilan dan tertangkap tangan. Untuk itu terdapat koordinasi antara lembaga dalam rangka penenggelaman kapal perikanan oleh Kementrian Kelautan dan Perikanan, Kejaksaan dan Pengadilan, namun koordinasi lembaga itu belum berjalan atau terlaksana dengan baik. Hal ini disebabkan karena belum jelas pengaturan mengenai standar operasional atau pedoman pelaksanaan pemusnahan atau penenggelaman kapal perikanan yang didalamnya mengatur tentang penyelenggaraan, mekanisme dan tata cara pemusnahan kapal untuk dijadikan landasan bagi Kementerian Kelautan dan Perikanan, Kejaksaan maupun Pengadilan dalam pelaksanaan penenggelaman kapal perikanan yang melakukan Illegal Fishing di wilayah perairan Indonesia.Untuk lebih mengoptimalkan pelaksanaan penenggelaman kapal maka diperlukan pengaturan diatur mengenai standar operasional atau pedoman pelaksanaan pemusnahan atau penenggelaman kapal perikanan yang didalamnya mengatur mengenai penyelenggaraan, mekanisme, dan tata cara pemusnahan kapal.

Undang-Undang Perikanan, mengamanatkan adanya tiga satgas sebagai satuan pengawasan perikanan, yaitu Polair, PPNS, dan TNI AL. Ketiga lembaga ini dinilai tidak efektif karena database informasi belum terkoordinasi serta sarana prasarana yang dimiliki belum menyatu sehingga menjadi tidak efisien. Di sisi lain, keberadaan Bakamla belum berperan optimal dalam melakukan fungsi koordinasi antar tiga lembaga tersebut. Sumber daya yang dimiliki oleh tiga lembaga yang terlibat dalam fungsi pengawasan tersebut seharusnya dapat dikonsolidasikan terutama dalam melakukan operasi penangkapan. Selain itu, keterbatasan sumber daya dan anggaran yang dimiliki Ditjen PSDKP yang mengakibatkan terbatasnya hari operasi dapat diatasi dengan melakukan koordinasi operasi dan wilayah penangkapan dengan DitPolair, TNI AL dan Bakamla sehingga tidak tumpang tindih dalam melakukan operasi penangkapan dan meminimalisasi celah kosongnya pengawasan karena keterbatasan pendanaan.

Kondisi yang disebutkan diatas menyebabkan perlunya peningkatan sarana dan prasarana penunjang dalam pelaksanaan kewenangan PPNS KKP agar lebih efektif, di antaranya adalah dengan pembangunan secara berkala, baik jumlah maupun ukuran kapal patroli yang disesuaikan dengan kondisi geografis wilayah operasi, pembangunan dermaga tambat labuh untuk kapal pelaku IUU Fishing sehingga memudahkan pengawasan dan menekan biaya sewa yang selama ini diberikan kepada TNI AL atau Polair, dan penyediaan dan peningkatan anggaran untuk seluruh proses penyidikan (mekanisme pencairan anggaran tidak dibatasi hanya untuk kasus yang telah P21). Selain itu, diperlukan peningkatan kapasitas penyidik PPNS baik secara kuantitas maupun kualitas, yang di antaranya dapat dilakukan melalui peningkatan jumlah PPNS, baik secara nasional maupun untuk wilayah-wilayah khusus yang sering terjadi IUU fishing, perlu juga adanya forum PPNS sehingga meningkatkan pengetahuan PPNS terhadap penanganan kasus-kasus IUU Fishing di lokasi lain, serta perlunya pembekalan bahasa asing yang sering digunakan oleh pelaku IUU Fishing dan pembuatan MoU antara PSDKP dan kejaksaan dalam proses penyidikan tindak pidana perikanan.

Permasalahan kewenangan terkait pelaksanaan atau eksekusi putusan pengadilan perikanan juga mengundang kontroversi yang cukup rumit antara Jaksa selaku Penuntut

16 Arman, Muhammad Razi. (2018). Polemik Penenggelaman Kapal Ikan Perikanan-Mengingatkan Pentingya Koordinasi, Harian Ekonomi Bursa, Jumat 18 Mei. 
Umum dengan Mantan Menteri Kelautan dan Perikanan Susi Pudjiastuti, karena adanya putusan-putusan pengadilan terkait perkara tidak pidana perikanan lebih banyak diambil alih oleh Susi Pudjiastuti yang pada saat itu selaku Menteri Kelautan dan Perikanan ketimbang dilaksakan oleh Jaksa selaku Penuntut Umum yang harus mengeksekusi Putusan Pengadilan Perikanan sesuai tugas dan kewenanganyang diberikan oleh UndangUndang Perikanan, Undang-Undang Kejaksaan, KUHAP maupun Undang-Undang Kekuasaan Kehakiman.

Penanganan illegal fishing selama ini dinilai tidak berjalan secara optimal. Hal tersebut terlihat dari tarik ulur kewenangan eksekusi putusan pengadilan perikanan antara instansi Kejaksaan dengan Instansi Kementerian Kelautan dan Perikanan yang terkait dalam kaitan dengan penegakan hukum di bidang illegal fishing tidak berjalan secara sinergis, bahkan cenderung berebut dan bersaing sesuai dengan kepentingannya masingmasing untuk mencapai popularitas.

\section{P E N U T U P}

Menurut Undang-Undang, ada dua cara penenggelaman kapal yang dilakukan oleh Pemerintah Republik Indonesia yaitu penenggelaman kapal melalui putusan pengadilan dan tertangkap tangan. Untuk itu terdapat koordinasi antara lembaga dalam rangka penenggelaman kapal perikanan oleh Kementrian Kelautan dan Perikanan, Kejaksaan dan Pengadilan, namun koordinasi lembaga itu belum berjalan atau terlaksana dengan baik. Hal ini disebabkan karena belum jelas pengaturan mengenai standar operasional atau pedoman pelaksanaan pemusnahan atau penenggelaman kapal perikanan yang didalamnya mengatur tentang penyelenggaraan, mekanisme dan tata cara pemusnahan kapal untuk dijadikan landasan bagi Kementerian Kelautan dan Perikanan, Kejaksaan maupun Pengadilan dalam pelaksanaan penenggelaman kapal perikanan yang melakukan Illegal Fishing di wilayah perairan Indonesia.Untuk lebih mengoptimalkan pelaksanaan penenggelaman kapal maka diperlukan pengaturan diatur mengenai standar operasional atau pedoman pelaksanaan pemusnahan atau penenggelaman kapal perikanan yang didalamnya mengatur mengenai penyelenggaraan, mekanisme, dan tata cara pemusnahan kapal.

\section{DAFTAR PUSTAKA}

\section{Buku}

[1] Akhmad, Solihin. (2017), Politik Hukum Kelautan Dan Perikanan, Bandung: Nuansa Aulia.

[2] Budiarjo, Miriam. (1998). Dasar-Dasar Ilmu Politik, Jakarta: Gramedia Pustaka Utama.

[3] Dahuri, Rohmin. (2012), Petunjuk Teknis Penyelesaian Perkara Tindak Pidana Perikanan, Jakarta: Pusdiklat Kejagung RI.

[4] Gatot: Supramono (2014), Hukum Acara Pidana \& Hukum Pidana Di Bidang Perikanan. Jakarta: Rineka Cipta.

[5] Husein, Harun M. (1991), Penyidikan Penuntutan dalam Proses Pidana, Cetakan Pertama, Jakarta: Rineka Cipta.

[6] Marlina, dan Faisal. (2013), Aspek Hukum Peran Masyarakat Dalam Mencagah Tindak Pidana Perikanan. Jakarta: Sofmedia.

[7] Nikijuluw, Victor P.H. (2008), Blue Water Crime: Dimensi Sosial Ekonomi Perikanan Illegal. Jakarta: Pustaka Cidesindo. 
[8] Nugraha, Aditya Taufan, dan Irman.(2008), Perlindungan Hukum Zona Ekonomi Ekslusif (ZEE) Terhadap Eksistensi Indonesia Sebagai Negara Maritim.Bandung: Citra Aditya.

[9] Nugraha, Aditya Taufan, dan Irman. (2008), Perlindungan Hukum Zona Ekonomi Ekslusif (ZEE) Terhadap Eksistensi Indonesia Sebagai Negara Maritim. Bandung: Citra Aditya.

[10] Prakoso, Djoko. (1985), Eksistensi Jaksa di Tengah-Tengah Masyarakat, Cetakan Pertama, Jakarta: Ghalia.

[11] Surachman, R.M. Hamzah, Andi. (1996). Jaksa di Berbagai Negara, Peranan dan Kedudukannya, Cetakan Pertama, Jakarta: Sinar Grafika.

[12] Tim Penyusun, (1989), Kamus Besar Bahasa Indonesia, Jakarta: Balai Pustaka

\section{Jurnal dan Lain-Lain}

[13] Arman, Muhammad Razi. (2018). Polemik Penenggelaman Kapal Ikan PerikananMengingatkan Pentingya Koordinasi, Harian Ekonomi Bursa, Jumat 18 Mei.

[14] Kementerian Kelautan dan Perikanan. (2015). Laporan Kinerja Satu Tahun Kementerian Kelautan Dan Perikanan Tahun 2015. Jakarta

[15] Muchsin. (2006). Menyongsong Kehadiran Pengadilan Perikanan, Jakarta : Varia Peradilan Tahun XXI No. 247 Juni

[16] http://nasional.kompas.com,Kapal.Pencuri.Ikan.Ditenggelamkan.di.Penjuru.Indone sia 